\title{
A Difícil Tarefa de Consolidação dos Direitos Humanos Diante da Problemática do Linchamento na Redemocratização do Brasil
}

\section{José Welhinjton Cavalcante Rodrigues}

Advogado pela OAB-PB. Especializando em Direito Penal pela Faculdade de Filosofia, Ciências e Letras de Cajazeiras (FAFIC). E-mail: welhinjtoncavalcante@gmail.com.

\section{Resumo}

Este artigo trata do linchamento ocorrido no Guarujá-SP, em 2014, que vitimou uma mulher inocente, como desafio à consolidação dos direitos humanos. Observado esse fenômeno sob uma abordagem racional ou instrumental, a partir do método dedutivo e do procedimento bibliográfico, constatou-se que o linchamento questiona o valor único e irrepetível que se atribui à singularidade da vida humana, e surge como uma manifestação, legitimada pelos seus membros, de justiça popular. Desse atrito resultam graves violações de direitos humanos que obstaculizam a consolidação democrática desses direitos. Em vista disso, surge a necessidade de ressignificação de valores essenciais, como a vida, a segurança e a liberdade, o que pode implicar a maior promoção dos direitos humanos e a redução dos linchamentos.

Palavras-chave: Redemocratização. Justiça popular. Direitos humanos. 


\title{
The Difficult Task of the Human Rights Consolidation Within the Lynching Problematic in the Brazil's Re-Democratization
}

\begin{abstract}
This article deals with the lynching happened in Guarujá-SP, in 2014, that had victimized an innocent woman, as a challenge to the consolidation of the human rights. Reviewing this phenomenon through a rational or an instrumental perspective, using a deductive and bibliographical procedure methods, it was found that lynching questions the unique and unrepeatable value attributed to the singularity of the human life, and comes as a manifestation, legitimized by its members, of popular justice. This friction results in several gross human rights violations that hinders the consolidation of those rights. Therefore, it comes the necessity of a re-signification of essential values, such as the life, the security and the freedom, what might provide a higher human rights promotion and fewer cases of lynching.
\end{abstract}

Keywords: Re-democratization. Popular justice. Human rights.

Recebido em: 7/7/2016

Revisões requeridas em: 26/4/2017

Aceito em: 2/5/2017

\section{Sumário}

1 Introdução. 2 0s direitos humanos. 2.10 conceito de direitos humanos. 2.2 A evolução dos direitos humanos. 2.3 A precarização dos direitos civis no Brasil. $3 \mathrm{~A}$ (des)legitimidade da justiça popular. 4 As características do linchamento no Brasil. 50 caso do Guarujá - São Paulo (2014). 6 Considerações finais. 7 Referências. 


\section{INTRODUÇÃO}

Nas últimas décadas são frequentemente noticiados numerosos casos de linchamentos que têm ocorrido pelo Brasil ao arrepio da lei. De acordo com informações oficiais, registrou-se no Brasil, entre o período de 1980 e 2006, um total de 1.179 casos de linchamento. ${ }^{1}$ Dados mais recentes apontam ainda que apenas no primeiro semestre de 2014 ocorreram mais de 50 casos de linchamentos. ${ }^{2}$ Entre eles, será objeto deste estudo o linchamento de uma mulher que ocorreu no Guarujá, São Paulo.

A história recente do país revela um cenário de grandes mudanças políticas, sociais e econômicas, o que tem servido de campo fértil para o crescimento da criminalidade. Assim sendo, apesar de serem constantemente expostos, pouco se tem produzido cientificamente sobre linchamentos no Brasil.

A respeito dos linchamentos, os estudos de Martins $(1995,1996)$ são pioneiros no país e são frequentemente referenciados nas poucas discussões acadêmicas existentes, assim como os trabalhos de Benevides (1982), Benevides e Ferreira (1983) e Rios (1988). As produções sociológicas dos mencionados pesquisadores encaram o linchamento como um ato coletivo violento, irracional e patológico.

Um enfoque diferente, no entanto, tem sido levantado. Os trabalhos sociológicos recentes têm atribuído ao linchamento significação racional típica de um meio cultural que lhe preenche de sentido e manifesta uma

${ }_{1}$ As informações foram levantadas pelo Núcleo de Estudos da Violência da Universidade de São Paulo (NEV/USP) e estão disponíveis no Banco de Dados da Imprensa. Disponível em: <http://www.nevusp.org/downloads/linch_brasil.htm>.

2 D’AGOSTINO, Rosanne. Dias de Intolerância. G1. Disponível em: <http://g1.globo.com/ politica/dias-de-intolerancia/platb/>. Acesso em: 11 jul. 2015. 
lógica de funcionamento. Nesse sentido, merece destaque a abordagem sociológica de Oliveira (2010) e Sinhoretto (2001, 2009), amplamente discutida neste artigo.

Não apenas na literatura sociológica que o linchamento é um problema difícil de ser tratado, mas representa também um desafio dos mais difíceis para o ideário dos direitos humanos, por que existem aqueles que condenam a prática pela brutalidade utilizada e por violar bens jurídicos tão prezados pela comunidade humana, apesar de haver outros, especialmente os linchadores, que enxergam o linchamento como uma forma eficaz de resolução de conflitos, não sendo poucas as vozes que anunciam seus bons resultados no restabelecimento da paz e da ordem no bairro.

Nesse sentido, o presente estudo põe em pauta a reflexão sobre os linchamentos acontecidos no Brasil durante sua redemocratização, notadamente por meio da análise do caso que ocorreu no Guarujá-SP, em 2014, tomando o compromisso internacional do Estado brasileiro com o respeito e a promoção dos direitos humanos dentro do seu território como parâmetro. Para viabilizar essa meta, o linchamento é tratado sob uma abordagem racional ou instrumental.

A partir da compreensão do aumento dos linchamentos como uma herança da ditadura militar que o país vivenciou (1964-1985), apesar de se saber que não é um fenômeno que acontece unicamente desde esse período, visa-se a identificar suas causas, de modo a buscar soluções por meio de ações que levem os direitos humanos a sério.

Os desafios para pesquisar sobre os linchamentos são amplos. Primeiro, por que as fontes de pesquisa são bem restritas, mesmo com o progresso tecnológico que tem possibilitado o registro de várias ações coletivas violentas, por exemplo, mediante o uso de aparelhos celulares, câmeras fotográficas, etc. Depois, devido aos registros policiais que acabam por classificar os linchamentos como homicídios ou tentativas de homicídio. 
Os dados utilizados nesta pesquisa são derivados dos noticiários dos jornais impressos e/ou virtuais. Isso ocorre devido ao fato de ser esta a principal fonte sistemática disponível, em âmbito doméstico. Não obstante, o caso do linchamento no Guarujá-SP foi gravado por um dos linchadores, com o vídeo sendo facilmente localizado no YouTube, no qual, por meio da busca das palavras "linchamento de Fabiane Maria”, é possível alcançar 118 resultados sobre o assunto.

\section{OS DIREITOS HUMANOS}

A ideia de relacionar os direitos humanos com o linchamento pode soar como algo subversivo quando se busca racionalizar a prática dos atores sociais envolvidos nesse fenômeno. Reforça essa percepção o fato de, nas últimas décadas, grupos oprimidos terem feito uso dos desses direitos como ferramenta de transformação da ordem dominante, o que esclarece o porquê do esforço de alguns grupos conservadores em associar a causa dos direitos humanos à mera proteção de indivíduos que praticaram um crime (RABENHORST, 2014).

Esse argumento, todavia, não se sustenta, pois os direitos humanos vão além da esfera penal e têm em sua pauta de reivindicações questões relacionadas aos direitos ambientais, aos direitos de minorias, aos direitos dos índios, a redução das desigualdades sociais e econômicas, etc., nos espaços democráticos brasileiros. Mesmo assim vale lembrar que até as pessoas que praticaram um crime grave têm direitos essenciais que devem ser respeitados. $\mathrm{O}$ indivíduo que pratica um crime pode vir a perder sua liberdade, mas jamais sua dignidade (RABENHORST, 2014). Então, os direitos humanos podem servir como um poderoso antídoto contra estruturas de dominação, favorecendo o respeito pela dignidade de grupos vulneráveis. 
A construção da cidadania no Brasil mostra com alguma frequência que os atores sociais oprimidos têm se utilizado da violência como uma das principais formas de reivindicação. $\mathrm{O}$ linchamento seria uma interface capaz de exemplificar essa situação na atualidade. Acontece que os direitos humanos não aprovam o emprego da violência como instrumento de reivindicação social, vindo, por vezes, a questionar seu uso por parte do próprio Estado, entendido como detentor legítimo do monopólio da violência.

Foi precisamente contra as mais diversas formas de violência que assolaram profundamente a humanidade que se desenvolveu o consenso de que os seres humanos devem ser reconhecidos como possuidores de direitos inatos. Pode-se destacar, portanto, que os direitos humanos guardam relação com valores e interesses considerados fundamentais e que não podem ser trocados por outros valores e interesses tidos como secundários (RABENHORST, 2014).

Parece haver algum consenso na cultura ocidental de que os seres humanos são detentores de determinados direitos em virtude de sua dignidade, ou seja, do valor absoluto que eles possuem (RABENHORST, 2014). A dignidade é uma qualidade intrínseca do ser humano que impede que cada pessoa seja instrumentalizada a servir a projetos de outros. A pessoa como sujeito de fins e que é um fim em si, deve assim tratar a si mesmo e ao outro. A dignidade estaria entre aqueles bens que não têm preço, portanto não pode ser substituída. A vida humana não pode ser barganhada por nada de equivalente, uma vez que cada ser humano é único (KANT, 2004).

Ao contrário das coisas, cada pessoa tem dignidade, isto é, um valor incondicionado e absoluto que vai além de todos os demais (RABENHORST, 2014). Por isso, os seres humanos devem ser sempre tratados com igual respeito e consideração, ou seja, como um fim em si mesmo. Cada vez que se suprimem direitos e garantias processuais de alguém, de 
maneira arbitrária, como é o caso do linchamento, se está a violar a sua dignidade e, consequentemente, a desrespeitar seus direitos humanos e fundamentais.

\subsection{Conceito de Direitos Humanos}

Os direitos humanos representam uma ideia profundamente revolucionária, pois resultam de muitos sacrifícios. Para que ela fosse alcançada, a História registrou os horrores da violência, como "Milhões de negros africanos capturados, traficados e transformados em escravos por toda a América. Milhões de índios dizimados por guerras e doenças trazidas pelos colonizadores. Milhões de judeus mortos pelos nazistas em campos de concentração" (RABENHORST, 2014, p. 5).

Sem embargo, os direitos humanos equivalem aos direitos relativos à dignidade dos seres humanos. São direitos que cada indivíduo tem pelo simples fato de ser humano, e que buscam resguardar seus possuidores contra qualquer forma de aviltamento (COMPARATO, 2007). Essa nova mentalidade impede a coisificação da pessoa humana e a supressão dos seus direitos essenciais, inclusive por meio da violência.

Tratados por Dworkin (2011) como "trunfos”, aquelas cartas que nos jogos de baralho têm um valor especial, podendo ganhar de quaisquer outras, os direitos humanos exercem papel valioso no plano jurídico. Isso porque

[...] o Estado poderia desejar matar todos os suspeitos de cometerem delitos em nome da redução da criminalidade. Contudo, caso isso viesse a acontecer, poderíamos evocar em nossa defesa a existência de valores mais importantes, tais como a vida e a integridade física dos seres humanos. Na metáfora de um jogo que estaríamos a jogar contra o Estado, tais valores funcionariam como trunfos ou coringas (RABENHORST, 2014, p. 5). 
O mesmo raciocínio não valeria para as outras pessoas? Acertadamente, pode-se concluir que sim. A violação de direitos humanos acontece não apenas por parte daqueles que detêm o poder estatal. A violência empregada com o fito de pôr fim à vida de outra pessoa vai de encontro a qualquer noção básica de direitos humanos, mesmo que praticada por aqueles que não têm o poder estatal, de modo que esses direitos poderiam ser invocados como trunfos para reclamar do Estado a tutela da segurança pública e a proteção do direito à vida daqueles que estão sob sua guarda.

Mesmo considerando os direitos humanos como trunfos, isso não significa que esses direitos sejam absolutos, no sentido de que devem ser observados incondicionalmente. Por exemplo, o direito à liberdade de expressão não permite que um indivíduo ofenda outras pessoas, uma vez que estas têm direito à honra e à vida privada. Assim, todo direito precisa ser ponderado para que seja avaliado seu peso ou importância, bem como sua compatibilidade com o interesse coletivo (RABENHORST, 2014).

\subsection{A Evolução dos Direitos Humanos}

Não nascem todos juntos, e não permanecem para sempre, ao contrário, os direitos humanos são construídos e reconstruídos ao longo do tempo, já lembravam Bobbio (1988) e Arendt (1989). A história de expansão dos direitos humanos, apesar de sistematizá-los em gerações, não implica a hierarquização desses valores, mas apenas situá-los em determinado momento histórico e em ordenamentos jurídicos específicos.

No século 18 surgem os primeiros direitos humanos denominados de direitos de primeira geração, são os direitos civis e políticos. Eles representam a emancipação do indivíduo que sempre se submeteu a grupos sociais como a família, o Estado, a religião, etc. (COMPARATO, 2007). Assim, esses direitos referem-se às liberdades individuais, isto os tornou conhecidos como "direitos-liberdade". 
A segunda geração, que surgiu no século 19, corresponde aos direitos sociais, econômicos e culturais. Esses direitos têm o Estado como sujeito passivo, pois dele é exigido o dever de realizar prestações positivas no sentido de suprir as necessidades básicas dos cidadãos, bem como propiciar o exercício das liberdades individuais (RABENHORST, 2014). Por isso, são conhecidos como "direitos-prestação”.

O século 20 foi bastante frutífero para os direitos humanos. Nele ganharam destaque os direitos de titularidade difusa, notadamente o direito ao desenvolvimento, à paz, ao meio ambiente protegido, etc. (RABENHORST, 2014). Esses direitos requerem a existência de uma consciência coletiva na atitude de cada pessoa pertencente à sociedade. Em seguida, surgiram os direitos no que diz respeito à proteção dos animais, da natureza e dos embriões.

Os direitos econômicos, sociais e culturais e os direitos civis e políticos são interdependentes e, em um espaço democrático, servem de trunfos para permitir que as pessoas, mesmo em meio a tantas diferenças, tenham os mesmos direitos básicos promovidos e respeitados, contudo, a precarização dos direitos civis pode vir a prejudicar a promoção dos direitos sociais, por exemplo.

Os direitos humanos civis na realidade brasileira, desde a redemocratização do país, sofrem devido ao agravamento de problemas com a segurança individual e são, entre os direitos que compõem a cidadania, os que apresentam enormes deficiências no que se relaciona a sua extensão e garantia. Assim, a compreensão do linchamento como forma de violência que obstaculiza o exercício da cidadania plena pode desaguar nesse quadro crítico de falta de efetivação dos direitos civis no Brasil.

\subsection{A Precarização dos Direitos Civis no Brasil}

A sociedade brasileira, egressa da ditadura militar, há três décadas, vem experimentando, entre outras tendências, o crescimento da violência urbana, as graves violações de direitos humanos que comprometem a con- 
solidação da democracia e a explosão de conflitos nas relações intersubjetivas, mais especificamente conflitos de vizinhança que frequentemente são direcionados para desfechos fatais (ADORNO, 2002). Essas tendências relacionam-se entre si, apesar de não ser possível afirmar que surgem de causas comuns.

A violência tornou-se um fenômeno corriqueiro, que se deve, entre outros fatores, ao rápido e desorganizado crescimento das cidades brasileiras que se urbanizaram em pouco tempo. Se em 1960, a população da área rural ainda superava a urbana, nos anos 2000 esse quadro se reverteu, uma vez que $81 \%$ da população brasileira já ocupava áreas urbanas. Com as grandes cidades, aumentaram o desemprego, o trabalho informal e o tráfico de drogas, que combinados, favoreceram a proliferação da violência, sobretudo na forma de homicídios dolosos (CARVALHO, 2006).

Os direitos humanos civis, que correspondem aos direitos à vida, à liberdade e à igualdade, são atingidos gravemente nesse contexto. O medo e a insegurança têm sido emoções que acompanham os cidadãos brasileiros nos mais diferentes espaços democráticos. Impedidos de frequentar determinados lugares, de sair de casa depois de um horário específico, o direito de ir e vir ganhou uma ressignificação cultural para pessoas que moram em bairros pobres, fazendo parecer mais um privilégio. Uma cidadania limitada é o que sobrou para os "cidadãos simples". ${ }^{3}$

\footnotetext{
3 A expressão "cidadãos simples” evoca a divisão em classes lançada por Carvalho (2006), e se refere aos cidadãos de segunda classe que estão submetidos aos rigores e benefícios da lei. São pessoas que frequentemente não têm noção exata dos seus direitos, e quando a têm, não dispõem dos meios suficientes para exigi-los. Ainda nesse sentido, há os "elementos" que ocupam os noticiários policiais. Essas pessoas são a grande população marginal das grandes cidades e têm seus direitos civis constantemente desrespeitados por outros cidadãos, pelo governo e pela polícia. Não é de se estranhar que os "elementos" receiem, por isso, o contato com autoridades legais.
} 
A falta de garantias eficazes dos direitos civis traz implicação com a maneira como a população busca resolver seus conflitos. Em 1988, 4,7 milhões de pessoas maiores de 18 anos envolveram-se em conflitos. Desse número, apenas $62 \%$ buscaram socorro na Justiça para solucioná-los, de acordo com o Instituto Brasileiro de Geografia e Estatística (IBGE). Em estudo mais recente sobre vitimização e acesso à Justiça, consta na Pesquisa Nacional por Amostra de Domicílios (Pnad), de 2009, que 12,6 milhões de pessoas, também maiores de idade, vivenciaram situações de conflito, e dessas pessoas que viveram conflitos no âmbito criminal somente $52,4 \%$ recorreram aos tribunais e Juizados. Isto é, as pessoas têm confiado cada vez menos na Justiça formal para resolver seus litígios.

O problema da ausência de garantias eficazes dos direitos civis é ainda mais agravado quando se verifica o profundo hiato entre a expansão da violência e o desempenho da Justiça criminal, o que resulta na impunidade penal. No Brasil, tudo indica que os crimes que mais permanecem impunes são aqueles em que ocorrem graves violações de direitos humanos, como acontece com os homicídios consumados durante linchamentos (ADORNO, 2002).

Os direitos civis são particularmente importantes, por que sua garantia baseia-se na existência de uma Justiça eficiente, barata e acessível a todas as pessoas. Como ficou demonstrado, a Justiça criminal brasileira tem sérias dificuldades de atender a base da garantia desses direitos, não apenas pela impunidade penal, mas também por não dar conta do crescimento da criminalidade, o que gera insegurança e indignação.

Essas informações reforçam um dado seríssimo: a população brasileira, notadamente a que habita bairros pobres, vê cada vez menos as instituições oficiais de Justiça como uma alternativa para solucionar seus conflitos. Tomar as rédeas da própria vida envolve, nesse contexto, a busca 
por aplicar uma justiça sem intermediações, que constantemente resulta em desfechos violadores de direitos básicos, com o linchamento sendo apenas uma das formas de realizar esse feito.

O problema da precarização dos direitos civis significa um empecilho ao ideal de cidadania plena desenvolvido no Ocidente. Cidadão pleno é aquele que usufrui dos direitos civis, políticos e sociais. Em contrapartida, há os cidadãos incompletos, que são aqueles que possuem apenas alguns desses direitos, e os cidadãos não completos que compreendem aquelas pessoas que não se beneficiam de nenhum desses direitos (CARVALHO, 2006). Sob essa perspectiva, a consolidação dos direitos humanos é base para viabilizar o exercício da cidadania.

Considerando que os direitos humanos civis, políticos e sociais são interdependentes, a cidadania tem sido um valor pouco contemplado para a população que vive em bairros pobres, incapaz de ter garantido o acesso a direitos básicos. A consequência funesta é percebida na realidade social por meio da violência cíclica que interrompe, limita e/ou paralisa vidas, gerando a estagnação do desenvolvimento político da sociedade.

Entre os direitos civis posto em xeque pela violência está o direito humano e fundamental à vida. Esse é o primeiro direito que qualquer indivíduo deve ter. Ele está consagrado em documentos jurídicos internacionais e domésticos, e no Direito brasileiro está previsto na legislação constitucional e infraconstitucional. $\mathrm{O}$ direito essencial de todos e de cada um à vida digna é a grande causa da humanidade, a principal energia que movimenta o processo civilizatório (BARROSO; MARTEL, 2010).

Na sociedade ocidental, a preservação da vida, como um valor em si, único e irrepetível, é um dos consensos mínimos que compõem a dignidade humana, de modo que negar o direito à vida a alguém implica o não reconhecimento da dignidade humana como atributo intrínseco de toda pessoa (BARROSO; MARTEL, 2010). Assim, convencionou-se que a vida tem um valor intrínseco e inviolável. 
De uma leitura dworkiana extrai-se que "uma coisa é intrinsecamente valiosa, [...], se seu valor for independente daquilo que as pessoas apreciam, desejam ou necessitam, ou do que é bom para elas” (DWORKIN, 2003, p. 99). Logo, o linchamento manifesta-se como um fenômeno moralmente problemático na medida em que destruir uma coisa que vale por si mesma representa uma terrível profanação.

\section{A (DES)LEGITIMIDADE DA JUSTIÇA POPULAR}

O linchamento é uma ação de protesto e reivindicação que pode surgir de um meio comunitário instável, no qual se busca expurgar do seu convívio aquele(s) que transgride (m) regras moralmente aceitas quase que hegemonicamente pela comunidade, aplicando-lhe(s) uma punição sem intermediações (SINHORETTO, 1998). A ação coletiva de execução sumária é revestida pelo anseio dos participantes de alcançarem outra forma de justiça, cuja prática segue códigos diferentes das ações tomadas pelas instituições estatais. Acontece que a justiça formal é vista como ineficaz no atendimento de demandas punitivas (OLIVEIRA, 2010), caracterizando um descompasso entre a ideia de justiça praticada pelos linchadores daquela adotada pelo Estado.

A ação particular torna-se uma solução possível e de resultados sentidos pela população (SINHORETTO, 2009). A esse respeito, note-se o depoimento de um popular entrevistado quando diz: "Porque a gente não deseja o mal para os outros, mas no caso, o que aconteceu... a gente não deseja o mal, mas também... sei lá, foi bom, no caso foi bom porque limpou o lugar, né?” (SINHORETTO, 1998). Assim sendo, mesmo discordando do emprego da violência, os cidadãos acabam por legitimar o linchamento, devido aos seus efeitos concretos para a manutenção da ordem e da paz na comunidade, argumento este utilizado para promover a ideia de que a criminalidade deve ser combatida de maneira arbitrária e violenta. 
Encontra-se, com isso, instaurado o conflito entre a forma popular e a maneira legal de se fazer justiça. Para entender as origens e mecanismos que engendram a discussão sobre justiça popular, ora dialoga-se com a concepção de Foucault (1992) a respeito do assunto desenvolvida durante um debate com ativistas maoístas, quando tratou da criação de tribunais populares para realizar o julgamento de crimes de polícia.

Durante o debate, Foucault explica que o tribunal não pode ser uma manifestação da justiça popular, uma vez que esta é caracterizada exatamente por ser antijudiciária. Isso tem sua razão de ser no fato de o tribunal representar essencialmente o aparelho de Estado da Justiça moderna, sendo, portanto, a figura do poder de uma classe. Dessa forma, uma Justiça que pretende ser popular e libertadora não pode utilizar como meio para alcançar suas metas, uma instituição que por excelência pertence ao Estado e tem por objetivo controlar a “plebe”. É importante destacar que para fundamentar seu argumento, Foucault (1992) apresenta alguns dados históricos.

Continua o mencionado autor ressaltando que um tribunal é um embrião criado pelo Estado, porque supõe uma terceira parte neutra que não tem interesse direto no conflito instalado e que, portanto, não participa dos conflitos de classe. Esta terceira parte é quem determina o que se entende por certo e errado, bem como sobre quem é o culpado, e isso vai de encontro à reivindicação principal da justiça popular, que consiste no direito de decidir por si próprio (FOUCAULT, 1992).

Logo, as ações de justiça popular são marcadamente antijudiciárias e diferem da forma do tribunal na medida em que reconhecem neste uma ferramenta do Estado e um meio de expressão do poder de classe. Em raciocínio oposto, uma ação pode ser caracterizada como manifestação de justiça popular quando seus objetivos e resultados guardam harmonia 
com a luta política do povo. Isso implica que rebelião e justiça popular são concepções que estão intimamente relacionadas, pois a justiça popular é um procedimento que nega o poder dominante (FOUCAULT, 1992).

O linchamento detém um viés de conflito de racionalidades, o que se depreende das ideias estabelecidas por Thompson (1979) por meio da perspectiva do relativismo cultural, por que é por meio deste que se confere aos sujeitos históricos certa racionalidade por intermédio do conceito de legitimidade. ${ }^{4}$ Isso favorece a compreensão de que as revoltas evidenciam a defesa de direitos e costumes harmônicos reivindicados por cidadãos.

O conflito de legitimidades corresponde à tensão entre normas tradicionais e modernas, que caminham para uma resolução radical nos momentos de crise. Nesse ínterim, o linchamento aparece claramente como uma revolta popular, mais abrangente, marcante e significativa do que a mera execução de um suposto criminoso (SINHORETTO, 2009). À parte o discurso que aborda o ato de linchar como irracional, pretende-se aqui distanciar a abordagem dos linchamentos daquela feita pelo senso comum.

Em suma, essa interpretação ilumina a compreensão acerca do linchamento, uma vez que este nega uma Justiça legal que não consegue resolver os conflitos e a expiação do crime, demandados no seio da comunidade, constituindo isso, portanto, rota direta de obstrução da comuni-

4 A ideia de legitimidade está diretamente relacionada ao consenso atingido no exercício do poder. Este consenso consiste na possibilidade de garantir a obediência sem que se recorra à utilização da força. Assim, os fundamentos do exercício do poder possuem harmonia com o sistema de crenças das pessoas que os reconhecem como legítimos. De tal modo, quando a estrutura de poder é observada como oposta a esse sistema de crenças, tem-se a contestação de sua legitimidade e a busca pela alteração de aspectos básicos da vida política, argumenta Johnson (1987). 
cação entre as discutidas formas de Justiça. Enquanto a Justiça legal não atende às demandas comunitárias, é o agir por conta própria um instrumento de realização da Justiça.

\section{AS CARACTERÍSTICAS DO LINCHAMENTO NO BRASIL}

Algumas pesquisas em torno dos linchamentos, notadamente os estudos de Benevides (1982, 1983), Rios (1988) e Martins (1996) trazem evidências no sentido de rotular a decisão que resulta no linchamento e o ato em si, como irracional e patológico. Por outro lado, as pesquisas recentes da Sinhoretto (2009) e Oliveira (2010) analisam essa ação coletiva como componente de um meio cultural que lhe atribui uma racionalidade, lhe preenche de sentido, bem como lhe expõe uma lógica de funcionamento.

O linchamento no Brasil manifesta-se com características bem delimitadas em diferentes situações, repetindo-se caracteres peculiares dos variados tipos de localidades (áreas metropolitanas, urbanas não metropolitanas e rurais) (MARTINS, 1996). De tal sorte que os estudos realizados em torno da temática permitiram uma sistematização em torno de um padrão acerca dos perfis dos linchados e dos linchadores, além da motivação e de onde ocorrem.

No Brasil os linchamentos constantemente são definidos como ações coletivas de execução sumária de pessoas, acusadas ou supostamente acusadas de transgredirem a ordem comunitária, observam Benevides (1982), Benevides e Ferreira (1983) e Sinhoretto (2009). Em estudo anterior, no entanto, Benevides (1982) considerou o linchamento como resultado de uma “revolta popular”. Divergências à parte, a característica principal dessa prática é a “(...) ação única: o grupo linchador se forma em torno de uma vítima e, após a ação, se dissolve” (SINHORETTO, 2009). 
Decorre então que essas ações são frequentemente abordadas como espontâneas e sem anterior preparo, iniciando-se de forma inesperada. Não obstante isso os participantes podem ter planejado, organizado e até previsto o resultado.

Em um estudo feito por Martins (1996) foram condensados aproximadamente 677 casos de linchamentos consumados e tentados que ocorreram durante um período de 20 anos. Desta pesquisa desdobram-se quatro categorias de linchadores, que contemplam (A) "parentes e amigos de alguém que tenha sido vítima do linchado", (B) "vizinhos e moradores da localidade de moradia de alguém que tenha sido vítima", (C) grupos corporativos de trabalhadores (especificamente motoristas de táxi e trabalhadores da mesma empresa em que trabalha ou trabalhava alguém vitimado) e (D) grupos ocasionais (especialmente multidões da rua, transeuntes, passageiros de trens e ônibus, torcedores de futebol). Assim sendo, os linchadores, geralmente, habitam o mesmo espaço comunitário e são “conhecidos de vista” (MARTINS, 1996).

Observa-se constantemente que os linchamentos funcionam como "rituais de desumanização" daqueles que infringem normas comunitárias, consubstanciados na eliminação simbólica da vítima. O linchado é submetido à expiação e suplício reais, por meio de mutilação, queimaduras, castração, esquartejamento, ou ainda de corpos arrastados pelas ruas e jogados no lixo, etc. (SOUZA, 1999). Diante disso, destaca-se um segundo centro da ação, que revela os linchamentos como agravamento da violência pelo sofrimento do corpo do outro.

Não são alvos de linchamento somente aqueles que cometem crimes de grande repúdio social, como estupro a crianças e adolescentes, homicídios, etc., mas também crimes contra o patrimônio, como furto, roubo, entre outros (RIOS, 1988). Sendo assim, o argumento de que o linchamento ocorre apenas em virtude de um crime que provoca ojeriza na comunidade é falacioso. Na verdade, as motivações que determinam o lin- 
chamento resultam de uma diversidade de fatores, e entre eles predomina a "indignação aguda com uma situação de opressão" (SINHORETTO, 2009). Existe posição diversa, defendida por Martins (1996), que acredita que as categorias $\mathrm{A}$ e $\mathrm{B}$ lincham por vingança, enquanto as categorias $\mathrm{C}$ e $\mathrm{D}$ o fazem pelo desejo de castigar.

Em pesquisa realizada pelo Núcleo de Estudos da Violência da Universidade de São Paulo (NEV/USP), foram levantadas 1.179 notícias acerca de linchamentos ocorridos no Brasil de 1980 a 2006. Novamente esse trabalho resultou em dados que consubstanciam os argumentos mencionados anteriormente, vez que se observou que os linchamentos encontram motivação em crimes de sangue (25\%), estupro (22\%) ou crimes contra a pessoa, assim como crime de roubo (26\%), invasão de residência e, inclusive, corrupção nas prefeituras. Resta evidente que, per si, não basta ser um crime que provoque comoção social, os linchamentos ocorrem no Brasil em virtude de questões de desigualdade política e econômica que integram a sensação de indignação social.

Nesse sentido, as diferentes motivações do linchamento podem ser assim distribuídas espacialmente:

Nas periferias das grandes cidades e nos municípios pequenos predomina um tipo de ação praticada por um grupo de pessoas que se conheciam ao menos de vista. São moradores do próprio local que se associam com seus vizinhos para realizar ações violentas com objetivo de devolver a ordem à região. Esse tipo de prática é mais freqüentemente denotado por um crime de sangue, ao passo que os linchamentos característicos dos centros das grandes cidades, em que os participantes não se conhecem, são mais comumente motivados por um crime contra a propriedade (SINHORETTO, 2009, p. 79).

Sob esse aspecto, há certa harmonia entre as ideias de Sinhoretto (2009) e Martins (1996), pois este defende disposição espacial semelhante àquela. Sendo assim, os linchamentos que acontecem no Brasil 
são fenômenos predominantemente urbanos, isso porque Martins (1996) atribui a concentração dessas práticas violentas em áreas urbanas a um processo social denominado de urbanização insuficiente e inconclusa, no qual há uma verdadeira privação no entendimento da lógica peculiar da vida urbana e civilizada. Não obstante, há também linchamentos em áreas rurais. Os linchamentos, portanto, ocorrem, em sua maioria, em regiões periféricas, em bairros pobres ou de classe média baixa, ainda em cidades pequenas e, em sua minoria, em áreas rurais.

A partir do exposto, Martins $(1989,1996)$ apresentou um perfil dual: os linchamentos de cidades pequenas que revelam uma percepção anti-iluminista, que contavam com a participação da classe média e a contestação expressa às instituições judiciárias e policiais, com base conservadora e repressiva; por outro lado os linchamentos das periferias urbanas são praticados por obreiros pobres, guardando forte motivação no anseio de justiça perante o acontecimento de crimes graves.

Outra classificação dual foi fornecida por Benevides e Ferreira (1983) e corresponde a linchamentos anônimos e comunitários. O tipo anônimo é aquele em que transeuntes de bairros de classe média que não foram diretamente atingidos pelo dissidente agregam-se a um linchamento mesmo sem conhecer sua origem, motivados pela invocação de "pega ladrão”. Em contrapartida, os linchamentos comunitários são aqueles em que uma comunidade, diante da possibilidade de ter seus indivíduos identificados em razão de todos se mobilizarem para o acontecimento, sente-se diretamente atingida pela conduta criminosa de um delinquente conhecido. As ações do perfil comunitário são comuns em cidades pequenas e bairros populares das periferias das metrópoles.

O linchamento ocorrido na primeira quinzena de maio de 2014, em Guarujá-SP, ora objeto da presente pesquisa, apresenta melhor subsunção nesta última classificação, por ter acontecido em um bairro popular. No caso em tela foi possível observar a mobilização da comunidade em torno 
da organização do linchamento, ora por meio dos limites territoriais do bairro, ora por intermédio dos recursos virtuais disponíveis. Ainda pode-se constatar o linchamento como revolta popular com contornos maiores do que a simples execução de uma suposta infratora. Assim, a execução vincula-se à reivindicação de segurança, ao reconhecimento político, etc. (SINHORETTO, 2009).

\section{O CASO DO GUARUJÁ - SÃO PAULO (2014)}

O linchamento aconteceu em um bairro do Guarujá de recente ocupação, marcado por um processo de urbanização lento e difícil, mas que originalmente possuía uma proposta restauradora para a região. Ocorre que a criação do bairro de Morrinhos surgiu como tentativa da prefeitura local de efetivar um programa de redução das 42 favelas existentes na cidade na década de 80 .

O bairro de Morrinhos pretendia abrigar 2.500 famílias vindas das Vilas Sônia, Julia e Baiana, em uma área de $665.840 \mathrm{~m}^{2}$. O terreno, contudo, foi sendo gradativamente ocupado irregularmente, mesmo não tendo iluminação pública, quaisquer condições sanitárias, transporte público, etc. (NASCIMENTO, 2008).

À época eram comuns denúncias de aquisição de lotes para revenda supostamente permitido pela prefeitura, motivo pelo qual alguns tentaram, sem êxito, instalar uma Comissão de Inquérito contra a administração pública local para apurar possíveis irregularidades, o que revela aspectos de corrupção e segregação nas relações de poder existentes entre as diversas instituições.

Apesar dos esforços desenvolvidos para efetivação do programa de desfavelamento, o bairro de Morrinhos tornou-se uma nova favela, espaço público propício para a desagregação e a exclusão social. Assim, 
o Morrinhos foi se estabelecendo sob sérios problemas socioeconômicos e políticos no cenário de um país que vivia profundas transformações em vários setores.

Atualmente uma das principais preocupações dos habitantes de Morrinhos é a criminalidade. A título de exemplo, a Folha de São Paulo (2014) realizou tabulação e constatou que, em 2013, a média de roubos no município do Guarujá foi quase três vezes maior que a média no Estado inteiro. Decorre daí a sensação crescente de insegurança na cidade, o que tem feito os moradores locais e os turistas alterarem sua rotina.

O linchamento, caso do presente estudo, aconteceu nos primeiros dias de maio de 2014 diante do clima de instabilidade e medo que estava presente na cidade. Há algum tempo começaram os boatos de que crianças estariam sendo sequestradas para serem sacrificadas durante rituais de magia negra, por uma mulher que ganhou traços mais específicos no imaginário social a partir de abril de 2014, quando foi divulgado seu possível retrato falado.

O retrato falado foi divulgado na página do Facebook "Guarujá Alerta” e rapidamente circulou pelos computadores, celulares e outros aparelhos eletrônicos dos moradores do Guarujá e região. Fica evidente nas reportagens feitas pelos jornais que a população estava mobilizada na identificação da criminosa.

$\mathrm{Na}$ tarde do dia 3 de maio, Fabiane Maria de Jesus retornava da igreja e teria ido comprar água em um bar, quando encontrou uma criança e lhe ofereceu uma banana. Nesse momento uma mulher gritou que Fabiane seria a suposta sequestradora. $\mathrm{Na}$ sequência, as pessoas a cercaram e passaram a agredi-la fisicamente, segundo relato presente no Portal R7 (2014). 
Rapidamente espalharam-se imagens de Fabiane, sendo identificada como a criminosa, o que serviu como convocação para outras pessoas. Inclusive a filha de Fabiane soube que estavam compartilhando no Facebook imagens da suposta sequestradora e ao ver sua mãe teve dificuldade de identificá-la, porque estava ensanguentada, de acordo com depoimento colhido pelo jornalista Campanha (2014).

O linchamento de Fabiane durou por volta de duas horas, dispõe relato apresentado pelo jornalista Ribeiro (2014b) ao Portal A Tarde. Entrementes, a vítima foi concomitantemente arrastada e espancada por uma rua do bairro Morrinhos, tendo seu corpo supliciado. Do linchamento resultaram imagens que têm sido utilizadas para a apuração dos responsáveis.

Nos vídeos que se encontram na Internet constata-se o sofrimento da vítima. Por vezes, esta recebe chutes e murros pelo corpo, além de ser apedrejada. Observa-se ainda, nos vídeos, que um dos linchadores, dispondo de um grande pedaço de madeira, desfere golpes contra a cabeça de sua vítima. Outro linchador, montado em uma bicicleta, usa-a como arma nas agressões. A vítima é ainda acorrentada pelo braço esquerdo e arrastada pelas ruas sob os gritos da grande multidão.

As imagens tornam perceptível, além das agressões que a vítima sofreu e como dezenas de pessoas ficavam ululantes diante delas, que algumas pessoas que assistiam ao linchamento pediam desesperadamente que os linchadores cessassem com a violência, apesar da indiferença destes. Assim, havia na multidão uma clara heterogeneidade de interesses.

O linchamento resultou na internação hospitalar e, dois dias depois, na morte da vítima em decorrência de traumatismo craniano e graves lesões corporais. Nos dias seguintes a polícia conseguiu identificar cinco suspeitos: dois denunciados anonimamente pela própria população, dois 
apresentaram-se espontaneamente após terem a prisão decretada e o outro foi capturado. A idade dos suspeitos varia de 18 a 48 anos, e todos possuem profissão especificada nas matérias dos jornais.

Não se pode esquecer que foi somente em virtude das fotografias e vídeos feitos do linchamento que a polícia conseguiu identificar e prender alguns suspeitos, porém mesmo arrependidos atribuíam a responsabilidade da violência praticada ao dono da página no Facebook "Guarujá Alerta”, razão pela qual este passou a receber ameaças de linchamento, conforme mostra o Portal G1 (2014). Assim sendo, nota-se no caso que os linchadores, apesar de lamentar a morte da vítima, ainda reconheciam a prática como uma forma legítima de punição.

\section{CONSIDERAÇÕES FINAIS}

Como ação imediata, a Comissão de Direitos Humanos e Minorias da Câmara dos Deputados, em maio de 2014, emitiu uma nota de repúdio contra os linchamentos que têm acontecido no Brasil, notadamente ao linchamento de Fabiane Maria de Jesus. Nessa mesma oportunidade a Comissão de Direitos Humanos convocou a impressa brasileira e os responsáveis pela difusão de conteúdos nas redes sociais a divulgarem ações que interrompam e não multipliquem ou incentivem as práticas violadoras de direitos humanos.

Foi realizada ainda uma audiência pública pela Comissão de Segurança Pública e Combate ao Crime Organizado, em maio de 2014, versando sobre a temática “Justiça com as próprias mãos”. Entre as discussões travadas voltou-se atenção à necessidade do governo de minimizar a impunidade e a ausência de ação do Estado como causas dos recentes casos de linchamento no Brasil. 
Apesar dos debates realizados, não há nesses movimentos uma medida que produza por si só transformação. $\mathrm{O}$ linchamento é um fenômeno social complexo, de modo que optar por uma solução simplista significaria apenas maquiar um problema estrutural do quilate da violência. Então, dentro dos limites traçados no decorrer deste estudo, pode-se estabelecer algumas ideias conclusivas.

O linchamento é uma grave violação aos direitos humanos de quem é vitimado e pode ser caracterizado, em parcela considerável dos casos, como um conflito de vizinhança de resultados fatais. Essa prática violenta, desde o início do período de redemocratização, tem aumentado como forma de resolução de conflitos e comprometido a consolidação da mentalidade de igualdade em respeito e consideração entre os membros da ordem política democrática no Brasil. Valores como a vida, a segurança e a liberdade têm comportado exceções legitimadas por uma justiça popular que, não raro, tem relativizado esses valores.

O caso do linchamento no Guarujá-SP compõe um cenário de banalização dos atos de violência pela mídia que acaba por espetacularizá-los, o que incita a manutenção de atitudes sociais ligadas a práticas violentas. Esse é um retrato da realidade social do Brasil, em que a desrespeito aos direitos civis repercute para gerar uma espécie de naturalização da violência. Uma mudança de atitude nesse sentido pode ser favorecida por meio da divulgação em rádios comunitárias e nas mídias sociais da importância do respeito aos direitos humanos. A realização de reuniões comunitárias para debater os problemas enfrentados no bairro e, por sua vez, formar pautas que serviriam para cobrar das autoridades locais políticas públicas em resposta aos problemas da violência poderia ser uma ferramenta de fortalecimento da cidadania.

Em contrapartida, o apoio das autoridades locais às exigências feitas pela população no sentido de buscar solucionar os problemas que forem da sua competência, ou mesmo servindo de porta-voz para a popu- 
lação quando for necessário recorrer a autoridades superiores, pode ser importante ação, capaz de permitir o exercício dos direitos humanos políticos. Dar voz aos cidadãos e subsidiar alternativas eficazes na solução dos conflitos sociais pode favorecer a redução dos linchamentos. A cidadania, seguindo esse raciocínio, tende a ser reforçada a cada nova demanda levantada.

Apesar da necessidade de conciliação entre as formas de justiça popular e legal que pode ocorrer pela utilização dos direitos humanos como interlocutor nesse diálogo, a discussão não se encerra com a adoção das medidas sugeridas. Há também a necessidade de que o Judiciário cumpra seu papel com alguma celeridade, pois o linchamento manifesta o conflito entre o que a população espera como punição justa e a resposta dada pelas instituições de Justiça, sem considerar que o tempo é importante para que se possa promover justiça para as partes.

A segurança pública merece ser abordada por ser ponto frequentemente reivindicado por linchadores. Se por um lado a Constituição de 1988 tirou o Exército do controle das polícias militares, passando-o ao governo dos Estados, por outro lado essa organização permaneceu com os traços militares, revelando-se uma instituição inadequada para garantir a segurança das pessoas. Mesmo a Polícia Civil não tem se mostrado adequada para garantir a segurança pública. Denúncias de tortura, o consentimento velado aos linchamentos, envolvimento em milícias e com criminosos, etc., são ações imputadas aos policiais. A desmilitarização das polícias pode ser uma resposta, notadamente à própria violência policial, herança que remanesce do período autoritário.

As pessoas andam tão sedentas por punição que isso já parece ser uma característica cultural legislativa. Novos crimes, novas penas ou a maximização das penas existentes, acredita-se que punição seja a única solução para a onda de violência que assola os brasileiros. A educação 
em direitos humanos pode ser uma importante aliada para mudar esse cenário, bem como a ideia de uma Justiça Restaurativa na esfera penal que caminha a passos lentos na realidade brasileira.

As propostas expostas não se apresentam como únicas alternativas possíveis e necessitam de outras ações, a exemplo do fomento à educação básica de qualidade, etc., que conjuntamente podem transformar realidades. Mesmo assim, são possibilidades a serem exploradas. Com isso, poderia ocorrer uma verdadeira ressignificação de valores essenciais, como a vida, a segurança e a liberdade, o que pode acarretar a redução dos linchamentos e a consolidação dos direitos civis e políticos e dos direitos econômicos, sociais e culturais.

\section{REFERÊNCIAS}

ADORNO, Sérgio. Exclusão econômica e violência urbana. Sociologias, Porto Alegre, ano 4, n. 8, p. 84-135, 2002.

ALMEIDA, Alfredo Wagner Berno de. Linchamentos: atos de justiça camponesa entre a humanização da penalidade e a desumanização do indígena. In: ANDRADE, Maristela de Paula. Justiça privada e tribunal: camponeses no banco dos réus? São Luís, 1997. (Col. Célia Maria Corrêa - Direito e Campesinato, vol. 2).

ARENDT, Hannah. Origens do totalitarismo. Trad. de Roberto Raposo. São Paulo: Companhia das letras, 1989.

BARROSO, Luís Roberto; MARTEL, Letícia de Campos Velho. A morte como ela é: dignidade e autonomia individual no final da vida. Revista da Faculdade de Direito de Uberlândia, v. 38, p. 235-274, 2010.

BENEVIDES, M. V. Linchamentos no Brasil: violência e justiça popular. São Paulo: Brasiliense, 1982. Disponível em: <http://www.cedec.org.br/files_pdf/ Aviolenciabrasileira.pdf $>$. Acesso em: 12 set. 2015. 
BENEVIDES, Maria Victoria; FERREIRA, Rosa Maria Fischer. Respostas populares e violência urbana: o caso de linchamento no Brasil (1979-1982). In: PINHEIRO, Paulo Sergio (Org.). Crime, violência e poder. São Paulo: Brasiliense, 1983.

BOBBIO, Noberto. A Era dos Direitos. Trad. Nelson Coutinho. $7^{\text {a }}$ ed. Rio de Janeiro: Elsevier, 2004.

CAMPANHA, Diógenes. Família de mulher linchada em Guarujá temia boatos sobre “bruxa”. Folha de S. Paulo, São Paulo, 11 maio 2104. Disponivel: <http:// www1.folha.uol.com.br/cotidiano/2014/05/1452689-familia-de-mulher-linchada-em-guaruja-temia-boatos-sobre-bruxa.shtml>. Acesso em: 3 jun. 2015.

CÂMARA. Comissão de Direitos Humanos divulga notas contra linchamentos públicos. Disponível em: <http://www2.camara.leg.br/camaranoticias/noticias/DIREITOS-HUMANOS/467285-COMISSAO-DE-DIREITOS-HUMANOS-DIVULGA-NOTA-CONTRA-LINCHAMENTOS-PUBLICOS.html>. Acesso em: 5 jun. 2015.

CAMPANHA, Diógenes. Família de mulher linchada em Guarujá temia boatos sobre ‘bruxa'. Folha de São Paulo. Disponível em: <http://www1. folha.uol.com.br/cotidiano/2014/05/1452689-familia-de-mulher-linchada-em-guaruja-temia-boatos-sobre-bruxa.shtml>. Acesso em: 11 maio 2014.

CARVALHO, José Murilo de. Cidadania no Brasil: o longo caminho. 8. ed. Rio de Janeiro: Civilização Brasileira, 2006.

COMPARATO, Fábio Konder. A afirmação histórica dos direitos humanos. São Paulo: Saraiva, 2007.

D’AGOSTINO, Rosanne. Dias de intolerância. G1. Disponível em: <http:// g1.globo.com/politica/dias-de-intolerancia/platb/>. Acesso em: 11 jul. 2015. DWORKIN, Ronald. Dominio da vida: aborto, eutanásia e liberdades individuais. Trad. Jefferson Luiz Camargo. São Paulo: Martins Fontes, 2003. . Justice for hedgehogs. Cambridge; London: Harvard University Press, 2011. 
FORACCHI, Marialice Mencarini. A participação social dos excluídos. São Paulo: Editora Graal, 1982.

FOUCAULT, Michel. Sobre a justiça popular. In: FOUCAULT, Michel. Microfísica do Poder. Rio de Janeiro: Graal, 1992.

GODOY, Marcelo. Polícia detém $2 \square$ acusado de participar de linchamento. A Tarde, Salvador, 8 maio 2014. Disponível em: <http://atarde.uol.com. br/brasil/noticias/1589952-policia-detem-2o-acusado-de-participar-de-linchamento>. Acesso em: 3 jun. 2014.

JOHNSON, Allan G. Dicionário de Sociologia: guia prático da linguagem sociológica. Trad. Sociologia Jurídica Ed. Saraiva, São Paulo, 1987.

KANT, Immanuel. Fundamentação da metafísica dos costumes. Porto Alegre: Livraria do Advogado, 2004.

LE BON, Gustave. Psychologie des Foules. 10. ed. Paris: Felix Alcan, 1905.

MARTINS, José de Souza. Linchamentos: a vida por um fio. Travessia, Centro de Estudos Migratórios, São Paulo, ano II, n. 4, p. 21-27, maio-ago. 1989.

As condições do estudo sociológico dos linchamentos no Brasil. Estud. av., São Paulo, vol. 9, n. 25, 1995. Disponível em: <http://www.scielo.br/scielo. php?script=sci_arttext\&pid=S0103-40141995000300022>. Acesso em: 15 maio 2015.

. Linchamento: o lado sombrio da mente conservadora. Tempo Social; Rev. Sociol. USP, São Paulo, 8 (2): 11-26, out. 1996.

MONTEIRO, André; TUROLLO JÚNIOR, Reynaldo. Guarujá teve a maior taxa de roubos no ano passado no Estado. Folha de São Paulo, São Paulo, 19 fev. 2014.

NASCIMENTO, José Roberto Santos do. O Bairro do Morrinho: origem e evolução na ocupação do solo. 2008. Trabalho de Conclusão de Curso (Graduação) - Faculdade Don Domênico, São Paulo, 2008. 
OLIVEIRA, Danielle Rodrigues de. Direitos humanos e linchamentos na região metropolitana de Belém. 2010. Disponível em: <http://www.ippur.ufrj.br/download/semana_pur_2010/completos/semanaippur2010.pdf>. Acesso em: 16 abr. 2016.

PORTAL A TARDE. Agência Estado. Guarujá: polícia tenta identificar mais dois suspeitos. A Tarde, Salvador, 13 maio 2014a. Disponível: <http://atarde. uol.com.br/brasil/noticias/1591250-guaruja-policia-tenta-identificar-mais-dois-suspeitos>. Acesso em: 3 jun. 2014.

Agência Estado. Polícia prende $3 \square$ suspeito de participar de linchamento. A Tarde, Salvador, 8 maio 2014b. Disponível: <http://atarde.uol. com.br/brasil/noticias/1590137-policia-prende-3o-suspeito-de-participar-de-linchamento>. Acesso em: 3 jun. 2014.

. Agência Estado. Quarto suspeito de participar de linchamento se entrega. A Tarde, Salvador, 9 maio 2014c. Disponível: <http://atarde.uol.com. br/brasil/noticias/1590313-quarto-suspeito-de-participar-de-linchamento-se-entrega>. Acesso em: 3 jun. 2014.

. Agência Estado. Quinto suspeito de linchamento no Guarujá se apresenta. A Tarde, Salvador, 12 maio 2014d. Disponível: <http://atarde.uol. com.br/brasil/noticias/1590888-quinto-suspeito-de-linchamento-no-guaruja-se-apresenta>. Acesso em: 3 jun. 2014.

PORTAL G1. MP acompanha investigação sobre linchamento em Guarujá. G1, São Paulo, 14 maio 2014. Disponível em: <http://g1.globo.com/sp/santos-regiao/noticia/2014/05/mp-acompanha-investigacao-sobre-linchamento-em-guaruja.html>. Acesso em: 16 jun. 2016.

PORTAL R7. Mulher foi espancada até a morte no Guarujá por causa de boato na Internet. R7, São Paulo, 5 maio 2014. Disponível: <http://noticias.r7.com/ sao-paulo/mulher-foi-espancada-ate-a-morte-no-guaruja-por-causa-de-boato-na-internet-07052014>. Acesso em: 3 jun. 2015. 
RABENHORST, Eduardo Ramalho. O que são direitos humanos? 2014. Disponível em: <http://www.cchla.ufpb.br/redhbrasil/wp-content/ uploads/2014/04/O-QUE-S\%C3\%83O-DIREITOS-HUMANOS.pdf>. Acesso em: 11 abr. 2016.

RIBEIRO, Bruno. Delegado espera prender suspeitos de linchamento hoje. A Tarde, Salvador, 6 maio 2014a. Disponível em: <http://atarde.uol.com. $\mathrm{br} / \mathrm{brasil} /$ noticias/delegado-espera-prender-suspeitos-de-linchamento-hoje-1589382>. Acesso em: 3 jun. 2014.

Suspeito de participar de linchamento de mulher é preso. A Tarde, Salvador, 6 maio 2014b. Disponível em: <http://atarde.uol.com.br/brasil/ noticias/1589440-suspeito-de-participar-de-linchamento-de-mulher-e-preso > Acesso em: 3 jun. 2014.

RIOS, José Arthur. Linchamentos: do arcaico ao moderno. Revista de Informação Legislativa, Brasília, v. 25, n. 100, p. 207-238, out./dez. 1988.

RONDELLI, Elizabeth. Imagens da violência: práticas discursivas. Tempo Social, São Paulo, v. 10, n. 2, p. 145-157, out. 1998. Disponível em: <http:// www.fflch.usp.br/sociologia/temposocial/site/images/stories/edicoes/v102/ imagens.pdf $>$. Acesso em: 23 nov. 2014.

SARLET, Ingo Wolfgang. Dignidade da pessoa humana e direitos fundamentais na Constituição Federal de 1988. Porto Alegre: Livraria do Advogado, 2007.

SINHORETTO, Jacqueline. Linchamentos: insegurança e revolta popular. Revista Brasileira de Segurança Pública, ano 3, ed. 4. fev./mar. 2009.

. Os justiçadores e sua justiça - linchamentos, costume e conflito. 2001. Dissertação (Mestrado em Sociologia) - Faculdade de Filosofia, Letras e Ciências Humanos, Universidade de São Paulo, São Paulo, 2001.

. Linchamentos e resolução de conflitos: estudos de casos da periferia de SP. ENCONTRO ANUAL DA ANPOCS, 22., 1998, p. 2. Disponível em: $<\mathrm{http}$ ///portal.anpocs.org/portal/index.php?option=com_docman\&task=doc_ view\&gid=5201\&Itemid=359>. Acesso em: 16 abr. 2015.

SOUZA, Lídio de. Judiciário e exclusão: o linchamento como mecanismo de reafirmação de poder. Análise Psicológica. Lisboa, v. 2, n. XVII, p. 327-338, 1999.

THOMPSON, E. P. Tradición, revuelta y consciencia de classe. Barcelona: Crítica, 1979. 